\title{
Improvement of Biomethane Potential by Anaerobic Co-Digestion of Sewage Sludge and Cocoa Pod Husks
}

\author{
Daniela Mora-Cortés ${ }^{1}$, Yeison Alberto Garcés-Gómez ${ }^{2 *}$, Sebastian I. Pacheco ${ }^{2}$ \\ ${ }^{1}$ Universidad Católica de Manizales, Environmental Engineering, Cra 23 No 60-63, 170001, Colombia \\ ${ }^{2}$ Universidad Católica de Manizales, Academic Unit in Natural Sciences and Mathematics, Cra 23 No 60-63, \\ 170001, Colombia
}

\begin{abstract}
The objective of this study was to determine the efficiency and theoretical stability of the anaerobic digestion of the wastewater sludge obtained from a municipal wastewater treatment plant, using co-digestion with cocoa pod husks. The chemical structure of sewage sludge, including its high carbon and nitrogen content in carbohydrates and fats, gives it vast potential for biomethane generation. In this study, the main agri-food residues in the geographical area where the study was conducted that could be used for co-digestion were determined, and cocoa pod husks were found to be the best option based on elemental chemical analysis. The results demonstrate that the codigestion of sewage sludge with cocoa pod husks can produce up to $555.7 \mathrm{LCH}_{\mathbf{4}} / \mathbf{K g ~ S V}$. In this article, we also propose a method for estimating biochemical methane potential (theoretical BMP) based on chemical equations and a systematic review of the most relevant research in BMP.
\end{abstract}

Keywords: Anaerobic digestion; Biomethane potential (BMP), Cocoa pod husks; Methane production; Sewage sludge

\section{Introduction}

Due to climate change and the global energy crisis, the world is searching a green and carbon-neutral energy source which could replace fossil fuels (Chin et al., 2019; Kusrini et al., 2019). The security of the energy supply, particularly through renewable energy, and the reduction of $\mathrm{CO}_{2}$ emissions have become priorities. The microbiological process of anaerobic digestion, which has long been known, is a promising and cheap method of producing biogas (Kusrini et al., 2016; Pilarska et al., 2019). Organic waste, including food waste, is increasingly being used in an attempt to solve another problem of the civilized world, namely the high production of waste. This technology is both a recipe for minimizing the harmful effect of waste on the environment and a source of methane, the biofuel of the future.

The conventional wastewater treatment plant sludge line generates a large amount of waste after decanting the solids from the primary (sedimentation) and secondary (biological) treatments. All the sludge is concentrated through different methods such as flotation, thickening, centrifugation, and dewatering. Variations in the quantity and quality of the mixed sludge are primarily defined by domestic and industrial habits, as well as by the correct functioning of the different treatment units (Alrawashdeh et al., 2017; AgaboGarcía et al., 2019). 
Different technologies are being widely studied to increase the potential of biomethane in anaerobic digestion processes (Ariyanto et al., 2017). These studies focused mainly on increasing the biodegradability of sludge by physicochemical, biological, and/or biochemical methods, thus improving the hydrolysis stage in the overall anaerobic digestion process (Tetteh et al., 2018). All these methods have led to higher recovery volumes and biomethane yields, even on a real scale, as a result of: (i) the rupture of the cell membranes of pathogens, which prevents competitiveness with microbial anaerobic digestion consortia; and (ii) the increase in available compounds, such as proteins, sugars, ammonia compounds, or volatile fatty acids that serve as food for anaerobic digestion consortia. A review of the most relevant research is presented in Table 1, taking into account that the articles mainly rely on the testing of the biochemical potential of domestic wastewater sludge in anaerobic systems and the different types of agricultural waste substrates used for co-digestion with this type of sludge. Parameters such as the type of reactor used and the inoculum/substrate ratio were also taken into account in the review.

Table 1 Summary of literature on methane production from sewage sludge and codigestion with other substrates

\begin{tabular}{|c|c|c|c|c|}
\hline Reference & Reactor type & $\begin{array}{c}\mathrm{BMP} \\
\left(\mathrm{LCH}_{4} / \mathrm{KgSV}\right) \\
\end{array}$ & Substrate & Co-digestion \\
\hline $\begin{array}{l}\text { Da Silva et al., } \\
2018\end{array}$ & $\begin{array}{l}\text { Retention time: } 15 \text { days; } \\
\text { vol: } 1600 \mathrm{~mL} \text { and } 240 \mathrm{~mL} \text {; } \\
\text { stages: } 1\end{array}$ & 311 & $\begin{array}{l}\text { sewage } \\
\text { sludge }\end{array}$ & glycerol \\
\hline $\begin{array}{l}\text { Aguilar et al., } \\
2017\end{array}$ & $\begin{array}{l}\text { Retention time: } 20 \text { days; } \\
\text { stages: } 1\end{array}$ & 205 & $\begin{array}{l}\text { sewage } \\
\text { sludge }\end{array}$ & food waste \\
\hline $\begin{array}{l}\text { Jianwei et al., } \\
2017\end{array}$ & $\begin{array}{l}\text { Retention time: } 15 \text { days; } \\
\text { stages: 1; Vol: } 1000 \mathrm{~mL}\end{array}$ & 203.4 & $\begin{array}{l}\text { sewage } \\
\text { sludge }\end{array}$ & old waste \\
\hline Zahedi et al., 2018 & $\begin{array}{l}\text { Retention time: } 20 \text { days; } \\
\text { vol: } 5000 \mathrm{~mL} \mathrm{c} / \mathrm{u}\end{array}$ & 800 & $\begin{array}{l}\text { sewage } \\
\text { sludge }\end{array}$ & glycerol \\
\hline Nielfa et al., 2018 & $\begin{array}{l}\text { Retention time: } 21 \text { days; } \\
\text { vol: } 10000 \mathrm{~mL} \text {; stages: } 1\end{array}$ & 523.8 & $\begin{array}{l}\text { sewage } \\
\text { sludge }\end{array}$ & $\begin{array}{l}\text { fruit } \\
\text { bunches oil } \\
\text { palm } \\
\text { residues }\end{array}$ \\
\hline Seo et al., 2017 & $\begin{array}{l}\text { Retention time: } 19,5 \text { days; } \\
\text { vol: } 1 \mathrm{~L}\end{array}$ & 200 & $\begin{array}{l}\text { sewage } \\
\text { sludge }\end{array}$ & -- \\
\hline $\begin{array}{l}\text { Sunwanee and } \\
\text { Chairat, } 2017\end{array}$ & $\begin{array}{l}\text { Retention time: } 45 \text { days; } \\
\text { vol: } 200 \mathrm{~mL}\end{array}$ & 196 & $\begin{array}{l}\text { sewage } \\
\text { sludge }\end{array}$ & $\begin{array}{l}\text { chicken } \\
\text { manure }\end{array}$ \\
\hline Guo et al., 2018 & $\begin{array}{l}\text { Retention time: } 17 \text { days; } \\
\text { stages: } 2 \text {; }\end{array}$ & 124.7 & $\begin{array}{l}\text { sewage } \\
\text { sludge }\end{array}$ & grape skins \\
\hline Thorin et al., 2017 & Retention time: 20 days & 210 & $\begin{array}{l}\text { sewage } \\
\text { sludge }\end{array}$ & micro-algae \\
\hline $\begin{array}{l}\text { Yongjun et al., } \\
2017\end{array}$ & $\begin{array}{l}\text { Retention time: } 14 \text { days; } \\
\text { vol: } 2000 \mathrm{~mL} \text {; }\end{array}$ & 105.6 & $\begin{array}{l}\text { sewage } \\
\text { sludge }\end{array}$ & -- \\
\hline $\begin{array}{l}\text { Aylin Alagöz et al., } \\
2018\end{array}$ & $\begin{array}{l}\text { Retention time: } 30 \text { days; } \\
\text { vol: } 1600 \text { ml; stages: } 1\end{array}$ & 110 & $\begin{array}{l}\text { sewage } \\
\text { sludge }\end{array}$ & $\begin{array}{l}\text { olives and } \\
\text { grape marc }\end{array}$ \\
\hline Passos et al., 2018 & $\begin{array}{l}\text { Retention time: } 15 \text { days; } \\
\text { vol: } 5000 \text { L; stages: } 2\end{array}$ & 196 & $\begin{array}{l}\text { sewage } \\
\text { sludge }\end{array}$ & $\begin{array}{l}\text { coffee } \\
\text { mucilage }\end{array}$ \\
\hline Amen et al., 2017 & $\begin{array}{l}\text { Retention time: } 14 \text { days; } \\
\text { vol: } 5000 \mathrm{~mL}\end{array}$ & 844 & $\begin{array}{l}\text { sewage } \\
\text { sludge }\end{array}$ & zeolite \\
\hline Nielfa et al., 2015 & $\begin{array}{l}\text { Retention time: } 39 \text { days; } \\
\text { vol: } 2000 \mathrm{~mL} \text {; }\end{array}$ & 221 & $\begin{array}{l}\text { sewage } \\
\text { sludge }\end{array}$ & solid wastes \\
\hline
\end{tabular}




\begin{tabular}{|c|c|c|c|c|}
\hline Reference & Reactor type & $\begin{array}{c}\text { BMP } \\
\left(\mathrm{LCH}_{4} / \mathrm{KgSV}\right) \\
\end{array}$ & Substrate & Co-digestion \\
\hline $\begin{array}{l}\text { Panomchai et al., } \\
2016\end{array}$ & $\begin{array}{l}\text { Retention time: } 48 \text { days; } \\
\text { stages: } 1 \text {; vol: } 5000 \mathrm{~mL}\end{array}$ & 200 & $\begin{array}{l}\text { sewage } \\
\text { sludge }\end{array}$ & $\begin{array}{l}\text { chicken } \\
\text { manure and } \\
\text { Napier grass }\end{array}$ \\
\hline $\begin{array}{l}\text { Sopee and } \\
\text { Natthanicha, } 2017\end{array}$ & $\begin{array}{l}\text { Retention time: } 30 \text { days; } \\
\text { stages: } 1\end{array}$ & 504.8 & $\begin{array}{l}\text { sewage } \\
\text { sludge }\end{array}$ & corn husk \\
\hline $\begin{array}{l}\text { Saowaluck et al., } \\
2014\end{array}$ & $\begin{array}{l}\text { Retention time: } 20 \text { days; } \\
\text { vol: } 5000 \mathrm{~mL} \text {; stages: } 1\end{array}$ & 191 & $\begin{array}{l}\text { sewage } \\
\text { sludge }\end{array}$ & $\begin{array}{l}\text { banana peel } \\
\text { and glycerol }\end{array}$ \\
\hline $\begin{array}{l}\text { Maamri and } \\
\text { Amrani, } 2014\end{array}$ & $\begin{array}{l}\text { Retention time: } 15 \text { days; } \\
\text { vol: } 5000 \mathrm{~mL} \text {; }\end{array}$ & 231 & $\begin{array}{l}\text { sewage } \\
\text { sludge }\end{array}$ & $\begin{array}{l}\text { bovine } \\
\text { manure }\end{array}$ \\
\hline $\begin{array}{l}\text { Wantanasak et al., } \\
2017\end{array}$ & $\begin{array}{l}\text { Retention time: } 45 \text { days; } \\
\text { vol: } 5000 \text { mL; stages: } 1\end{array}$ & 456 & $\begin{array}{l}\text { sewage } \\
\text { sludge }\end{array}$ & $\begin{array}{l}\text { palm oil } \\
\text { waste }\end{array}$ \\
\hline $\begin{array}{l}\text { Jagadish et al., } \\
2014\end{array}$ & $\begin{array}{l}\text { Retention time: } 60 \text { days; } \\
\text { vol: } 2000 \mathrm{~mL}\end{array}$ & 361 & $\begin{array}{l}\text { sewage } \\
\text { sludge }\end{array}$ & $\begin{array}{l}\text { water } \\
\text { hyacinths } \\
\text { and sheep } \\
\text { waste }\end{array}$ \\
\hline
\end{tabular}

The literature review of the co-digestion of sewage sludge in co-digestion with substrates revealed the following results. The keyword co-occurrence analysis of the search can be summarized in Figure 1, in which one can see the main keywords used in the literature are comprised of anaerobic digestion, sewage sludge, methane production, and food waste; the latter is of great importance due to the potential that can be found in countries with an agro-economy, due to the amount of unusable waste that can be generated in agro-food industry companies.

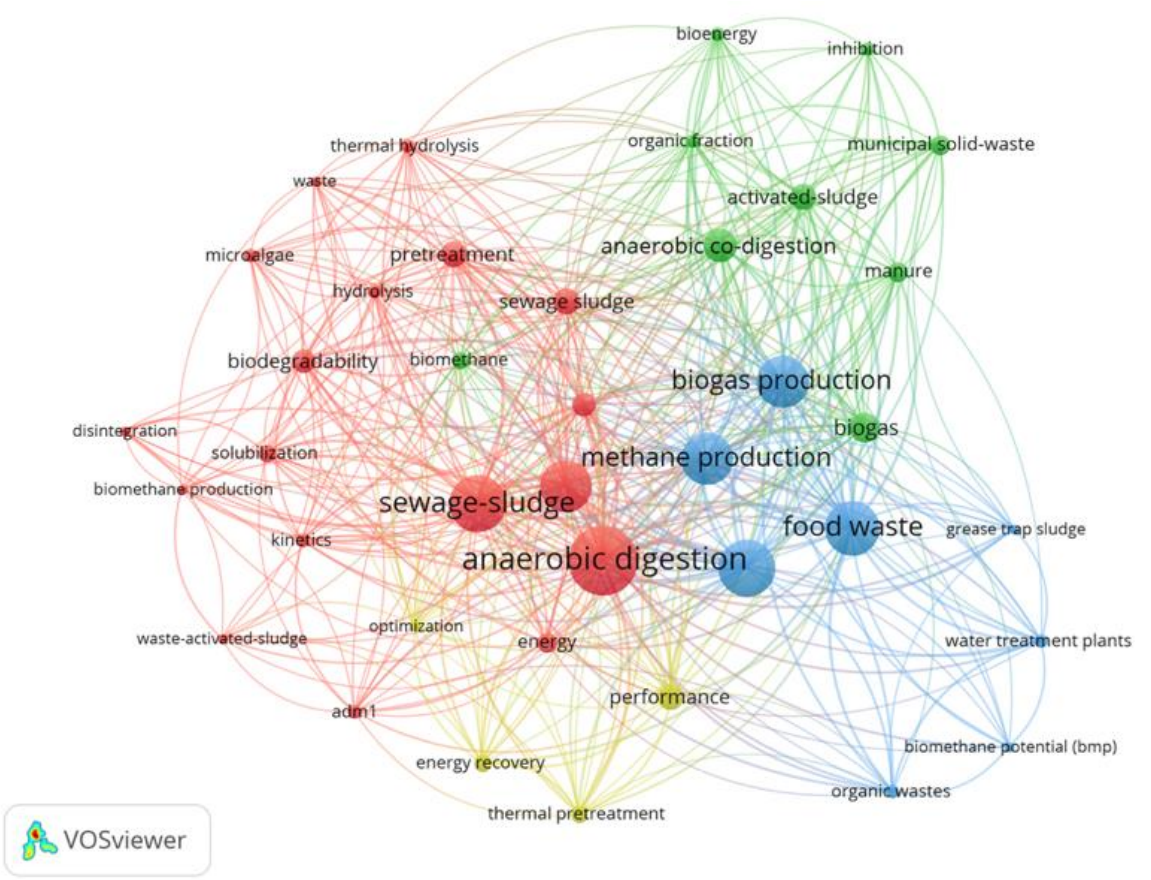

Figure 1 Co-occurrence analysis of the results of a WoS database search, analyzed with the VOSviewer tool (van Eck and Waltman, 2017)

The cocoa pod husks represents the largest byproduct of the chocolate industry, both in Colombia and worldwide. Currently, there has been an increase in related studies on this type of waste and its possible uses because it represents an important component of 
agricultural residues and global agro-industrial waste, constituting a promising source of renewable resources and energy (Ayeni, 2010). Colombia is the third-largest cocoa producer in Latin America after Brazil and Ecuador. In 2006, exports from the cocoachocolate chain totaled more than 56 million US dollars. In Colombia, cocoa occupies an important place among the most commercial agricultural products for the country, with a harvested area of 164,332 hectares or $2.8 \%$ of the total agricultural area. Cocoa production in the country has been characterized by its low level of technological development, in which only weed control, pruning, and harvesting are conducted. Cocoa is produced in almost all the departments of the country, but it is mainly concentrated in Santander, Nariño, Arauca, and Antioquia. Caldas, the study area, is the eighth largest producer with $4.1 \%$ of national cocoa production (Lu et al., 2018).

The present study was conducted in Victoria, a Colombian municipality located in the east of the department of Caldas, in the region known as Magdalena. The wastewater treatment plant there is operated by the department's public water treatment company. The plant stores about $25000 \mathrm{~m}^{3}$ of sludge per month, which is partly used by agricultural companies in the area for composting in the fertilization of some crops. Since the production of sludge far exceeds the need for fertilizer, most of the sludge, which is then dried, is sent to the municipality's landfill.

\section{Materials and Methods}

\subsection{Sewage Sludge of Municipal Solid Wastes}

The huge amount of sewage sludge and the organic fraction of municipal solid waste, which is disposed of daily through incineration or landfill, is a significant environmental challenge (Alrawashdeh et al., 2017; Pilarska et al., 2019). Waste sludge is considered to be treated sludge in three forms: primary sludge, secondary sludge, and mixed primary and secondary sludge (thickened sludge). Primary sludge is more easily degradable under anaerobic conditions than secondary sludge. Typical aerobic wastewater treatment is usually performed in a wastewater treatment plant with several scales of aerobic duration and sedimentation to reduce the biochemical oxygen demand and chemical oxygen demand of the waste before it is discharged or transported to surface waters. However, the primary and secondary treatment process releases a significant amount of methane, which is lost to the atmosphere, increasing the environmental impacts and decreasing the potential energy of the sludge. An anaerobic digestion process integrated with aerobic treatment would recover a significant amount of biogas for energy production treatment. Additionally, the possibility of treating OFMSW and sewage sludge together to produce biogas in a system possibly integrated with aerobic treatment has an interesting potential (Alrawashdeh et al., 2017). The BOD of the sewage was determined to be $30 \mathrm{~g} /$ day, with a retention time of 24 hours and a $\mathrm{pH}$ of $6-9$.

\subsection{Anaerobic Digestion}

Anaerobic digestion is defined as the process in which microorganisms decompose biodegradable material in the absence of oxygen, taking charge of stabilizing organic matter by converting it into humus and gases such as carbon dioxide and methane, the latter being the most abundant. The main benefit of anaerobic digestion is the methane gas produced, which can be used to produce electricity. One of the most widely used techniques for this purpose is co-digestion between organic waste (whether food or animal) and the primary sludge generated in wastewater treatment plants to convert it into methane $\left(\mathrm{CH}_{4}\right)$. The biochemical methane potential (BMP) test is a widely used analytical method in this type of technique, as it serves to quickly assess whether a residue can be correctly degraded to 
produce $\mathrm{CH}_{4}$. The experimental value is given as $m L \mathrm{CH}_{4} / g \mathrm{SV}$. The biodegradability of a substrate is indicated by the performance of $\mathrm{CH}_{4}$ (i.e., by the percentage of solids added or removed during anaerobic digestion).

One of the expressions used for the determination of BMP is the Buswell equation, which is based on the composition of the substrate and represents a balanced redox reaction in which the products of anaerobic digestion are methane, carbon dioxide, and ammonia (Bakraoui et al., 2020):

$$
\mathrm{C}_{a} \mathrm{H}_{b} \mathrm{O}_{c} \mathrm{~N}_{d}+\left(a-\frac{b}{4}-\frac{c}{2}+\frac{3 d}{4}\right) \mathrm{H}_{2} \mathrm{O} \rightarrow\left(\frac{a}{2}+\frac{b}{8}-\frac{c}{4}-\frac{3 d}{8}\right) \mathrm{CH}_{4}+\left(\frac{a}{2}-\frac{b}{8}+\frac{c}{4}+\frac{3 d}{8}\right) \mathrm{CO}_{2}+d \mathrm{NH}_{3}
$$

where $a, b, c$ and $d$ are the stoichiometric coefficients of the biodegradable molecules.

\subsection{Substrate Selection for Co-digestion}

Taking into account that we will be working with waste from the region to be used as a substrate, the cocoa pod husks was chosen because this one of the best options used in the co-digestion with waste sludge from the Victoria plant. The chemical composition of cocoa pod husks consist primarily of fibrous materials, including 19.7-26.1\% cellulose, 8.7-12.8\% hemicellulose, 14-28\% lignin, and 6.0-12.6\% pectin (Lu et al., 2018).

\subsection{Sample Analysis}

The results of the elemental analysis of the sewage sludge and completely dried cocoa pod husks are summarized in Table 2. The results were obtained using CN828 $(\mathrm{C}, \mathrm{H}, \mathrm{O}, \mathrm{N})$ and TGA801 (ash, volatile content) analyzers. The samples were taken using the ASTM D 5231-92 standard, which aims to define and report the composition of municipal solid waste through the selection and manual classification of waste samples.

Table 2 Results of elemental analysis of moisture-free substrate samples

\begin{tabular}{ccc}
\hline Chemical element & Sludge $\%$ & Cocoa pod husk \% \\
\hline Volatile solids & 57.65 & 68.82 \\
C & 32.34 & 45.4 \\
H & 4.88 & 5.33 \\
O & 20.30 & 37.81 \\
N & 5.84 & 1.31 \\
Ash & 35.81 & 9.86 \\
\hline
\end{tabular}

\subsection{Experimental Setup and Procedure}

For the determination of the Theoretical BMP, the results obtained from the proximate and elemental analysis of the samples of the plant's residual sludge and the substrates to be used for co-digestion were taken into account, in this case, the cocoa residue; from these, a stoichiometric balance of the moles of $\mathrm{CH}_{4}$ from $100 \mathrm{~g}$ of substrate was obtained (cocoa pod husks residue).

After analyzing the results from Table 2, the results were divided based on their respective atomic mass to find the molar value using Equation 2. Subsequently, the molar ratio of Carbon to Nitrogen was found using Equation 3, the molar ratio is intended to convert in a chemical reaction, the number of moles of one substance to the corresponding amount of moles of another substance.

$$
\begin{aligned}
& n=\frac{\text { elemental mass }(\mathrm{g})}{\text { atomic mass of the element }}=\text { moles } \\
& \text { Ratio }=\frac{\text { Moles of element }(n)}{\text { Moles of Nitrogen }}=\text { ratio } n: N
\end{aligned}
$$


This determines the ratios $C: N=6.56: 1$ y $C: N=41.8: 1$ for the sludge and the cocoa pod husks respectively.

Based on the molar ratio, the chemical formulas obtained are $\mathrm{C}_{6.56} \mathrm{H}_{11.9} \mathrm{O}_{3} \mathrm{~N}$ and $\mathrm{C}_{41.8} \mathrm{H}_{59.2} \mathrm{O}_{14.5} \mathrm{~N}$, which signifies the chemical composition of the sludge and the cocoa pod respectively.

The determination of the BMP was performed with a spreadsheet displayed in Table 3; the objective was to determine by iterative calculations the mass ratios for a matter balance and to find the total mass of the sum of the two substrates that meet the ratio $C: N=20-$ 25: 1 and the respective mass ratio of each. A ratio of $1000 \mathrm{~g}$ cocoa pod husks and $1000 \mathrm{~g}$ sewage sludge was initially assumed, taking into account the desired $C: N$ ratio for $\mathrm{n}$ iterations, a molecular weight of $1000 \mathrm{~g}$ cocoa pod, and $842 \mathrm{~g}$ sewage sludge was obtained.

Table 3 Determination of total mass using $1000 \mathrm{~g}$ cocoa and $842 \mathrm{~g}$ sewage sludge

\begin{tabular}{cccccrr}
\hline $\begin{array}{c}\text { Chemical } \\
\text { element }\end{array}$ & $\begin{array}{c}\text { \% Cocoa } \\
\text { pod husk }\end{array}$ & \% Sludge & $\begin{array}{c}\text { Mass cocoa } \\
\text { pod husk }\end{array}$ & Mass sludge & $\begin{array}{r}\text { Total } \\
\text { mass }\end{array}$ & \% Total \\
\hline C & 45.28 & 31.62 & 452.8 & 266.24 & 719.04 & 39.04 \\
$\mathrm{H}$ & 5.73 & 4.29 & 57.3 & 36.12 & 93.42 & 5.07 \\
$\mathrm{O}$ & 41.79 & 19.33 & 417.9 & 162.76 & 580.66 & 31.52 \\
$\mathrm{~N}$ & 1.23 & 2.52 & 12.3 & 21.22 & 33.52 & 1.82 \\
Ash & 5.97 & 42.24 & 59.7 & 355.66 & 415.36 & \multicolumn{1}{c}{22.55} \\
\hline & & & Total & 1842 & 100 \\
\hline
\end{tabular}

Iterative calculations allow one to determine that the highest efficiency in co-digestion is by using $86.44 \%$ of cocoa pod husks and $13.56 \%$ of sewage sludge.

From the total mass of both substrates, Table 4 displays the calculation of the chemical formula of the substrate-substrate mixture, and the calculation of their respective molecular weights; with this it is possible to determine the molar ratio for stoichiometry estimation in the Buswell equation. The chemical equation obtained is $\mathrm{C}_{25} \mathrm{H}_{39.02} \mathrm{O}_{15.16} \mathrm{~N}$.

Table 4 Calculation of molecular weight and molar ratio

\begin{tabular}{ccccc}
\hline Chemical element & $\%$ & Mass (g) & Moles (mole) & Molar ratio (\%) \\
\hline $\mathrm{C}$ & 39.04 & 39.04 & 3.25 & 25.01 \\
$\mathrm{H}$ & 5.07 & 5.07 & 5.07 & 39.02 \\
$\mathrm{O}$ & 31.52 & 31.52 & 1.97 & 15.16 \\
$\mathrm{~N}$ & 1.82 & 1.82 & 0.13 & 1 \\
\hline
\end{tabular}

Replacing in Equation 3 gives:

$$
\mathrm{C}_{25} \mathrm{H}_{39.02} \mathrm{O}_{15.16} \mathrm{~N}+8.42 \mathrm{H}_{2} \mathrm{O} \rightarrow 13.21 \mathrm{CH}_{4}+11.79 \mathrm{CO}_{2}+\mathrm{NH}_{3}
$$

According to the above results, it can be seen that with a molar ratio of $C: 25 ; H: 39.02$; $O: 15.16$ and $N: 1$, there is a molar production of methane, carbon dioxide and ammonia with values of $13.22 \mathrm{~mol}, 11.79 \mathrm{~mol}$ and $1 \mathrm{~mol}$, respectively per mole of substrate-cosubstrate mixture.

Based on the data in Table 3, the percentages of the mixture are given by using the ratio of $C: N=25: 1$ and then performing the calculation of the volatile solids (VS). The calculation for determining the mass of volatile solids in the mixture is:

$$
M_{V S}=1000 g * \frac{1173.61 g V S}{1842 g M T}=637.138 g V
$$


From a mass of $1842 \mathrm{~g}$, the substrate-co-substrate mixture (SCM) contains $1173.61 \mathrm{~g}$ in volatile solids. For $1000 \mathrm{~g}$ MSC that was originally assumed, there are $637.138 \mathrm{~g}$ of volatile solids (see Table 4).

- $\quad P P M_{S C M}=595.85 \mathrm{~g} / \mathrm{mol}$, assuming $1000 \mathrm{~g} \mathrm{SCM}$ (substrate-co-substrate mixture)

- $M_{S C M}=1000 \mathrm{~g}$

- $M_{V S}=637.138 g$

The moles with the molecular weight are obtained with Equation 4:

$$
\mathrm{mol}=\frac{\text { masa }}{\text { peso molecular }}=\frac{637.138 \mathrm{gSV}}{595.85 \mathrm{~g} / \mathrm{mol}}=1.07 \mathrm{~mol} \mathrm{VS}
$$

\section{Results and Discussion}

Stoichiometry was performed to calculate how many moles of $\mathrm{CH}_{4}$ are obtained per $1000 \mathrm{~g} \mathrm{SCM}$ and its equivalent in volatile solids $637.138 \mathrm{~g} \mathrm{VS}$.

$$
1.07 \mathrm{~mol} \mathrm{VS} \times \frac{13.21 \mathrm{~mol} \mathrm{CH}_{4}}{1 \mathrm{~mol} \mathrm{SV}}=14.37 \mathrm{~mol} \mathrm{CH}_{4}
$$

Once the molar amount of $\mathrm{CH}_{4}$ BMP was evaluated with the Equation 5:

$$
B M P_{\text {Teoretical }}=\frac{\mathrm{LCH}_{4}}{\mathrm{Kg}_{\text {Substrate }}}
$$

To determine the $L$ volume of methane, it was necessary to clear the ideal gas equation $P V=n R T$, where two local values are taken from the study zone. With the average temperature of the zone at $26^{\circ} \mathrm{C}=299.15 \mathrm{~K}=T$ and the atmospheric pressure $P=$ $0.9958 \mathrm{~atm}$, clearing we have:

$$
V=\frac{14.37 \mathrm{~mol}\left(0.082 \frac{\frac{\mathrm{L}}{\mathrm{atm}}}{\mathrm{mol} * \mathrm{~K}}\right) 299.15 \mathrm{~K}}{0.9958 \mathrm{~atm}}=353.98 \mathrm{~L}
$$

Therefore, the $B M P_{\text {Theoretical }}$ is:

$$
B M P_{T}=\frac{353.98 \mathrm{LCH} 4}{0.637 \mathrm{KgSV}}=555.7 \frac{\mathrm{LCH}_{4}}{\mathrm{Kg} \mathrm{SV}}
$$

The bibliographic reviews of the co-digestion processes with wastewater sludge were presented in Table 1, with special relevance of the BMP that has been achieved in the reviewed literature, demonstrating an average production of $310 \mathrm{~L} \mathrm{CH}_{4} / \mathrm{Kg} \mathrm{SV}$. The results of the elemental analysis of the substrate and co-substrate have been summarized in Table 2. From analytical development, it was found that the co-digestion of sewage sludge with cocoa pod husks in a ratio of 1: 0.842 generates a BMP of 555.7 $\mathrm{L} \mathrm{CH}_{4} / \mathrm{Kg} \mathrm{SV}$, a value that is well above the average reported in the literature. This implies that there is great local potential for biofuel production that can support other processes in the area, which can be scaled up nationally as a viable alternative to fossil fuels. Future research should aim to examine other local substrate wastes in the agro-food industry and conduct a scalability study for the country that primarily uses this wastewater treatment model. From the perspective of the use of cocoa pod shells as a co-substrate in the production of biogas, two important advantages can be determined. On the one hand, the cocoa pod husks are discarded by the farmers because composting is difficult due to the hardness of the husk, and they are regularly deposited in uncultivable places and without further use; on the 
other hand, the sludge produced by the wastewater treatment plant, which is used to a lesser extent as fertilizer due to its strong odor and very high production, is to a greater extent dried and discarded in the municipal landfill, reducing the capacity of the landfill. Taking this into account, the use of two waste products in the production of biogas not only reduces the generation of waste, but also promotes the generation of green energy.

\section{Conclusions}

The substrate ratio and concentration levels for biogas production were determined by co-digesting municipal sewage sludge and cocoa pod husks, an agro-food waste that was previously wasted in the study region, by means of an iterative process. A C:N ratio was achieved for high biogas production. The biogas yield demonstrating that this co-digestion is an efficient alternative, partly solving two problems, namely, the use of sludge which is mostly being deposited in the municipality's landfill site and the use of waste from the municipality's cocoa production. Further consideration should be given to increasing the representative sample with various types and quantities of food waste resources for use as a co-substrate from local production. The optimal conditions with stable biogas production from co-digestion between agri-food waste and domestic wastewater developed in this study will be used to expand biogas production plants on a commercial scale in future engineering applications. The municipal council is planning to develop a biogas plant to support familiar small industries in production with the use of the green fuel results of this research.

\section{Acknowledgements}

This work was supported by the Universidad Católica de Manizales with the research groups on Technological and Environmental Development GIDTA, and Education and Educators Traning EFE.

\section{References}

Agabo-García, C., Pérez, M., Rodríguez-morgado, B., Parrado, J., Solera, R., 2019. Biomethane Production Improvement by Enzymatic Pre-treatments and Enhancers of Sewage Sludge Anaerobic Digestion. Fuel, Volume 255, 115713

Aguilar, M.C., Wang, Y.D., Roskilly, T., Pathare, P.B., Lamidi, R.O., 2017. Biogas from Anaerobic Co-digestion of Food Waste and Primary Sludge for Cogeneration of Power and Heat. Energy Procedia, Volume 142, pp. 70-76

Alrawashdeh, K.A.B., Pugliese, A., Slopiecka, K., Pistolesi, V., Massoli, S., Bartocci, P., Bidini, G., Fantozzi, F., 2017. Codigestion of Untreated and Treated Sewage Sludge with the Organic Fraction of Municipal Solid Wastes. Fermentation, Volume 3(3), pp. 1-12

Amen, T.W.M., Eljamal, O., Khalil, A.M.E., Matsunaga, N., 2017. Biochemical Methane Potential Enhancement of Domestic Sludge Digestion by Adding Pristine Iron Nanoparticles and Iron Nanoparticles Coated Zeolite Compositions. Journal of Environmental Chemical Engineering, Volume 5(5), pp. 5002-5013

Ariyanto, T., Cahyono, R.B., Vente, A., Mattheij, S., Millati, R., Sarto, Taherzadeh, M.J., Syamsiah, S., 2017. Utilization of Fruit Waste as Biogas Plant Feed and its Superiority Compared to Landfill. International Journal of Technology, Volume 8(8), pp. 1385-1392

Ayeni, L., 2010. Effect of Combined Cocoa Pod Ash and NPK Fertilizer on Soil Properties, Nutrient Uptake and Yield of Maize (Zea mays). Journal of American Science, Volume 6(3), pp. 79-84 
Aylin Alagöz, B., Yenigün, O., Erdinçler, A., 2018. Ultrasound Assisted Biogas Production from Co-digestion of Wastewater Sludges and Agricultural Wastes: Comparison with Microwave Pre-treatment. Ultrasonics Sonochemistry, Volume 40(B), pp. 193-200

Bakraoui, M., Karouach, F., Ouhammou, B., Aggour, M., Essamri, A., El Bari, H., 2020. Biogas Production from Recycled Paper Mill Wastewater by UASB Digester: Optimal and Mesophilic Conditions. Biotechnology Reports, Volume 25, e00402

Chin, K.C., Leong, L.K., Lu, S.Y., Tsai, D.H., a/p Sethupathi, S., 2019. Preparation of Metal Organic Framework (MOF) Derived Bimetallic Catalyst for Dry Reforming of Methane. International Journal of Technology, Volume 10(7), pp. 1437-1445

Da Silva, C., Astals, S., Peces, M., Campos, J.L., Guerrero, L., 2018. Biochemical Methane Potential (BMP) Tests: Reducing Test Time by Early Parameter Estimation. Waste Management, Volume 71, pp. 19-24

Guo, L., Zhang, Z., Gao, M., She, Z., Zhao, Y., Guo, Y., Sun, J., 2018. Comparison of Thermophilic Bacteria and Alkyl Polyglucose Pretreatment on Two-stage Anaerobic Digestion with Waste Sludge: Biogas Production Potential and Substrate Metabolism Process. Bioresource Technology, Volume 249, pp. 694-703

Jagadish, H.P., Mal, A., Shankar, B., Kumar Mahesh, S., BP Pradeep, K., 2014. Anaerobic Codigestion of Water Hyacinth and Sheep Waste. Energy Procedia, Volume 52, pp. 572578

Jianwei, Z., Lin, G., Qilin, W., Yiwen, L., Dongbo, W., Bing-Jie, N., Xiaoming, L., Rui, X., Guangming, Z., QI, Y., 2017. Aged Refuse Enhances Anaerobic Digestion of Waste Activated Sludge. Water Research, Volume 123, pp. 724-733

Kusrini, E., Lukita, M., Gozan, M., Susanto, B.H., Widodo, T.W., Nasution, D.A., Wu, S., Rahman, A., Siregar, Y.D.I., 2016. Biogas from Palm Oil Mill Effluent: Characterization and Removal of $\mathrm{CO}_{2}$ using Modified Clinoptilolite Zeolites in a Fixed-bed Column. International Journal of Technology, Volume 7(4), pp. 625-634

Kusrini, E., Wu, S., Susanto, B.H., Lukita, M., Gozan, M., Hans, M.D., Rahman, A., Degirmenci, V., Usman, A., 2019. Simultaneous Absorption and Adsorption Processes for Biogas Purification using $\mathrm{Ca}(\mathrm{OH})_{2}$ Solution and Activated Clinoptilolite Zeolite/Chitosan Composites. International Journal of Technology, Volume 10(6), pp. 1243-1250

Lu, F., Rodriguez-Garcia, J., Van Damme, I., Westwood, N.J., Shaw, L., Robinson, J.S., Warren, G., Chatzifragkou, A., McQueen Mason, S., Gomez, L., Faas, L., Balcombe, K., Srinivasan, C., Picchioni, F., Hadley, P., Charalampopoulos, D., 2018. Valorisation Strategies for Cocoa Pod Husk and its Fractions. Current Opinion in Green and Sustainable Chemistry, Volume 14, pp. 80-88

Maamri, S., Amrani, M., 2014. Biogas Production from Waste Activated Sludge using Cattle Dung Inoculums: Effect of Total Solid Contents and Kinetics Study. Energy Procedia, Volume 50, pp. 352-359

Nielfa, A., Cano, R., Fdz-Polanco, M., 2015. Theoretical Methane Production Generated by the Co-digestion of Organic Fraction Municipal Solid Waste and Biological Sludge. Biotechnology Reports, Volume 5(1), pp. 14-21

Nielfa, A., Cano, R., Fdz-Polanco, M., 2018. Strategies for Improving Biogas Production of Palm Oil Mill Effluent (POME) Anaerobic Digestion: A Critical Review. Renewable and Sustainable Energy Reviews, Volume 82(3), pp. 2993-3006

Panomchai, W., Umaporn, K., Kulyakorn, K., 2016. Optimum Ratio of Chicken Manure and Napier Grass in Single Stage Anaerobic Co-digestion. Energy Procedia, Volume 100, pp. 22-25 
Passos, F., Cordeiro, P.H.M., Baeta, B.E.L., de Aquino, S.F., Perez-Elvira, S.I., 2018. Anaerobic Co-digestion of Coffee Husks and Microalgal Biomass After Thermal Hydrolysis. Bioresource Technology, Volume 253, pp. 49-54

Pilarska, A.A., Pilarski, K., Wolna-Maruwka, A., Boniecki, P., Zaborowicz, M., 2019. Use of Confectionery Waste in Biogas Production by the Anaerobic Digestion Process. Molecules, Volume 24(1), pp. 1-13

Saowaluck, H., Ubonrat, S., Siriorn, B., Nipon, P., 2014. Biomethane Production from Codigestion of Banana Peel and Waste Glycerol. Energy Procedia, Volume 61, pp. 22192223

Seo, K.W., Choi, Y.S., Gu, M.B., Kwon, E.E., Tsang, Y.F., Rinklebe, J., Park, C., 2017. Pilot-scale Investigation of Sludge Reduction in Aerobic Digestion System with EndosporeForming Bacteria. Chemosphere, Volume 186, pp. 202-208

Sopee, P., Natthanicha, S., 2017. Methane Production Potential from Anaerobic Codigestions of Different Animal Dungs and Sweet Corn Residuals. Energy Procedia, Volume 138, pp. 943-948

Sunwanee, J., Chairat, S., 2017. Kinetic Model of Biogas Production from Co-digestion of Thai Rice Noodle Wastewater (Khanomjeen) with Chicken Manure. Energy Procedia, Volume 138, pp. 386-392

Tetteh, E., Ansah Amano, K.O., Asante-Sackey, D., Armah, E., 2018. Response Surface Optimisation of Biogas Potential in Co-digestion of Miscanthus Fuscus and Cow Dung. International Journal of Technology, Volume 9(5), pp. 944-954

Thorin, E., Olsson, J., Schwede, S., Nehrenheim, E., 2017. Biogas from Co-digestion of Sewage Sludge and Microalgae. Energy Procedia, Volume 105, pp. 1037-1042

van Eck, N.J., Waltman, L., 2017). Citation-based Clustering of Publications using CitNetExplorer and VOSviewer. Scientometrics, Volume 111(2), pp. 1053-1070

Wantanasak, S., Kanathip, P., Jiravut, S., Sompong, O.-T., 2017. Anaerobic Co-digestion of Palm Oil Mill Waste Residues with Sewage Sludge of for Biogas Production. Energy Procedia, Volume 138, pp. 789-794

Yongjun, L., Min, G., Aining, Z., Lui, Z., 2017. Strengthen Effects of Dominant Strains on Aerobic Digestion and Stabilization of the Residual Sludge. Bioresource Technology, Volume 235, pp. 202-210

Zahedi, S., Rivero, M., Solera, R., Perez, M., 2018. Ultrasound Assisted Biogas Production from Co-digestion of Wastewater Sludges and Agricultural Wastes: Comparison with Microwave Pre-treatment. Fuel, Volume 215, pp. 285-289 